\title{
Farmers' work-related social security in Finland, implemented by Mela
}

\author{
Antti Huhtamäki
}

\begin{abstract}
Mela is the Farmers' Social Insurance Institution of Finland (in Finnish: Maatalousyrittäjien eläkelaitos) founded in 1969. It provides comprehensive pension cover and social security to farmers, reindeer herders, fishermen, forest owners and recipients of scientific or artistic grants and scholarships living in Finland. In addition to providing pension insurance (MYEL), Mela provides its customers: statutory occupational accident insurance, leisuretime accident insurance, Mela sickness allowance, occupational rehabilitation, group life insurance, and farm closure support for farmers and reindeer herders. It also administers the farmers' holiday and stand-in scheme, and provides advisory services related to occupational safety and wellbeing at work. The social security provided by Mela was originally addresses to farmers, reindeer herders, fishermen, forest owners. Since 2009 also recipients of scientific and artistic grants/scholarships are Mela's customers. This article presents the most important stages in the development of social insurance for agricultural entrepreneurs in Finland and the evolution of this system until today. It also explains different benefits offered by Mela and the rules of being subject to social insurance by Mela, as well as the financial economy of Mela, including Mela's sources of revenue. Finally, it presents tailored programmes and actions offered by Mela to the insured.
\end{abstract}

Keywords: farmers, Mela, pension cover, pension insurance, social security.

Antti Huhtamäki, Chief Operating Officer, Mela (Farmers' Social Insurance Institution), Finland. 


\section{Introduction}

The purpose of this article is to describe the earnings-related social security of Finnish farmers, which is provided by the Farmers' Social Insurance Institution Mela. In addition, the article briefly describes the welfare services and occupational safety work which are also carried out by Mela. This article is based on information published on websites by organisations that provide Finnish social security schemes, such as the Farmers' Social Insurance Institution Mela ${ }^{1}$, the Finnish Pension Alliance TELA ${ }^{2}$, the Finnish Centre for Pensions ETK $^{3}$ and the Social Insurance Institution of Finland Kela ${ }^{4}$.

For fifty years, Mela has provided comprehensive pension cover and social security to farmers, fishermen, reindeer breeders and forest owners living in Finland. Recipients of scientific and artistic grants/scholarships became Mela's customers as of the beginning of 2009. The Farmers' Pension Act has been in force since 1970, and Mela was founded in 1969. Mela's field of activity, its administration and sources of financing are laid down in law. However, Mela functions as a private insurance institution. Its administration includes representatives of both the insured and the State.

Mela handles the statutory earnings-related pensions (MYEL), employment accident insurance (MATA) and many other benefits for insured customers. The MYEL pension scheme and MATA accident insurance scheme are very similar to general schemes for other entrepreneurs and employed persons. In previous years there have been some extensions to the general pension scheme, e.g. the farmers' early retirement scheme, but they have been mostly abandoned now.

The number of insured farmers has declined strongly during the past few decades. As the pension scheme started 50 years ago, more than 400,000 farmers and their family members were insured. Today, the number of insured farmers and other insured persons is below 60,000, and the declining trend continues. The number of insured practitioners of science and art has increased, amounting to 5,000 people annually.

1. Mela, Farmers' Social Insurance Institution of Finland, http://www.mela.fi, access 15.062020.

2. Finnish Pension Alliance TELA, http://www.tela.fi, access 15.06.2020.

3. Finnish Centre for Pensions ETK, http://etk.fi, access 15.06.2020.

4. Kela, Social Insurance Institution of Finland, http://www.kela.fi, access 15.06.2020. 


\section{Who does Mela insure?}

Farmers' Pension Insurance (MYEL) is mandatory for those who fulfil the conditions of the insurance laid down in The Farmers' Pension Act. If the conditions of mandatory insurance are not met, the insurance can be in many cases taken out voluntarily.

The number of farmers insured is around 55,000, and the number of grant recipients around 5,000. The number of persons receiving pensions from Mela is around 110,000 . The MYEL insurance is based on earnings from farming and other activities on a farm. Farmers' earnings (calculated income) are mainly determined on the basis of the cultivated agricultural and forest areas. The earnings of fishermen are based on net sales. Reindeer breeders' income is calculated according to the number of reindeer and the number of days worked. Grant recipients' earnings are based on the amount of the grant or scholarship received from the state.

MYEL insurance for farmers is mandatory for farmers who:

- live in Finland,

- work as farmers, forest property owners, professional fishermen or reindeer breeders,

- work as independent entrepreneurs (spouses and other family members who in participate agricultural work are also entitled to insurance),

- are between 18 and 69 years of age,

- have been self-employed without interruption for at least four months, and

- have a calculated annual income of at least EUR 3980 per year (in 2020) and have at least 5 ha of arable land.

MYEL insurance for grant and scholarship recipients is mandatory whenever the following criteria are met:

- the grant is awarded for work that lasts a minimum of four months,

- the amount of the grant for the four-month period is at least 1,330 euros (2020),

- the grant is awarded from Finland,

- the recipient of the grant is not employed by the grant provider,

- the recipient of the grant is between 18 and 68 years of age. 


\section{Insurance premiums and financial economy of Mela}

\section{Financing and insurance contributions of earnings-related pensions}

Generally, earnings-related pensions are financed from pension contributions and from returns on investments made by pension funds. Financing is mainly based on the pay-as-you-go system: the required amount of insurance premiums is collected each year to cover the earnings-related pensions paid. However, in the private sector some of the pension contributions paid each year are put into a fund for future years. In Finland, the pension systems of self-employed persons and farmers are financed by pension contributions and tax revenues and follow the principles of the pay-as-you-go system.

The general earnings-related pension contribution is an insurance premium that is collected from all employees aged 17 and over and self-employed persons aged 18 and older. In 2020, the average pension contribution for private-sector employees is $24.4 \%$ of their wages. The employee's share is $7.15 \%$ for under-53-year-olds and for those who have turned 63 . The share is $8.65 \%$ for $53-62$-year-olds. The employer pays the rest.

Farmers, as self-employed persons, are themselves responsible for their pension contributions. The confirmed income stated by a self-employed person forms the basis for their earnings-related pension and for other social security, benefits and contributions also. In 2020, a self-employed person's/farmer's pension contribution was $24.1 \%$ of their confirmed income if they are under 53 years of age or have turned 63. Those who are 53-62 years old paid $256 \%$.

Farmers' pensions are financed using the pay-as-you-go principle, i.e. without funding. Because the number of people receiving farmer's pensions is double the number of people insured, the pension contributions collected annually are not enough to cover the annual pension expenses. This is the main reason why the state budget covers the shortfall existing between the pension payments and the contributions collected.

The determination of the premium rate is based on three elements: calculated income from the farm, the rate of the employment pension premium under the general scheme and the agricultural entrepreneurs' cut-rate system. The difference between the actual pension cost and the premium income is paid by the state.

The general premium rate is adopted annually by the Ministry of Social Affairs and Health, and in 2020 the rate was $24.4 \%$ of an individual's salary. When earning 
up to an annual calculated income of approx. $€ 27,900$, farmers pay $54 \%$ of the total premium, and for income exceeding the above sum, the premium rate increases gradually up to the general premium rate. Due to the relatively low-income level, farmers' average premium rate is approximately $13.9 \%$ of their calculated income.

\section{Financing of occupational accident insurance and disease scheme and insurance premiums}

Farmers pay for one third of the costs of the occupational accident and disease scheme. The Finnish Social Insurance Institution pays 37\%, and approximately $30 \%$ comes from the state budget. Farmers' premiums are calculated on the basis of calculated income from their farms. The premium rate is on average $1.0 \%$ of the calculated income. Total compensation in the amount of $€ 31$ million was paid out in 2020 for 8,900 accidents at work.

The costs of personal accident insurance are fully covered by insurance premiums paid by farmers. In 2019, compensation for personal accidents was paid out for 1,194 accidents, amounting to a total of $€ 4$ million.

\section{Financing of the sickness allowance scheme}

The sickness allowance scheme is fully financed from the state budget. In 2019, sickness allowances worth a total of almost $€ 3$ million were paid out to 8,000 farmers.

\section{Financing of the holiday and stand-in scheme}

The state is responsible for financing the annual holiday scheme. When using substitute assistance, the farmer pays a fee based on his/her calculated income from the farm. The average price paid by the farmer is from $20 \%$ to $25 \%$ of the general market price. The difference between the actual costs and the premium incomes is paid from the state budget.

\section{Mela's expenditure and sources of revenue in 2020}

Insured customers pay $€ 185$ million to Mela in insurance contributions. The state's share of expenditure is $€ 949$ million, and the share of the Finnish Social Insurance Institution is $€ 9$ million. Other pension institutions pay $€ 92$ million. The return on investments is $€ 17$ million. Operating expenses are estimated to reach $€ 35$ million. 
Mela's expenditures and sources of revenue are as follows:

Figure 1. Mela's Expenditure 2020,€ 1228 million (budget)

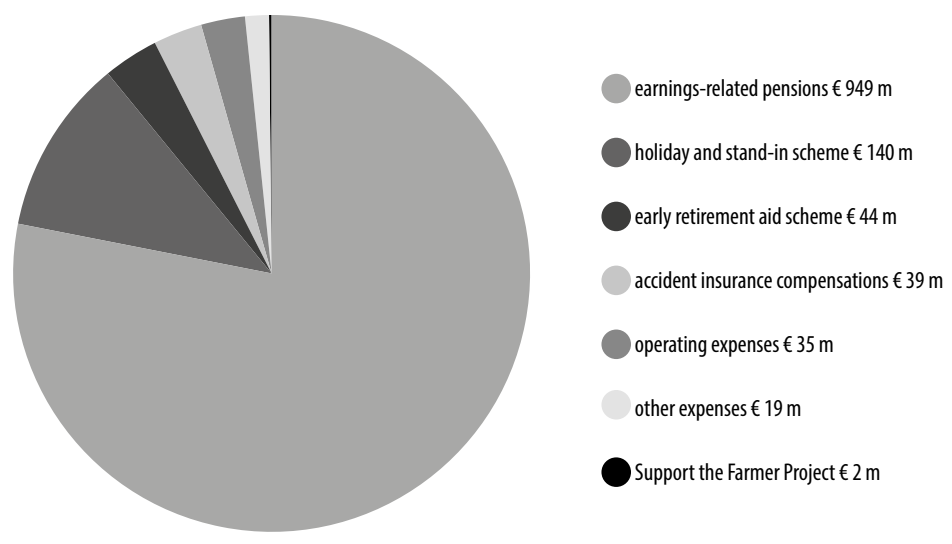

Source: Mela, Farmers' Social Insurance Institution of Finland, http://www.mela.fi, access 15.062020.

Figure 2. Mela's Sources of Revenue 2020, $€ 1228$ million (budget)

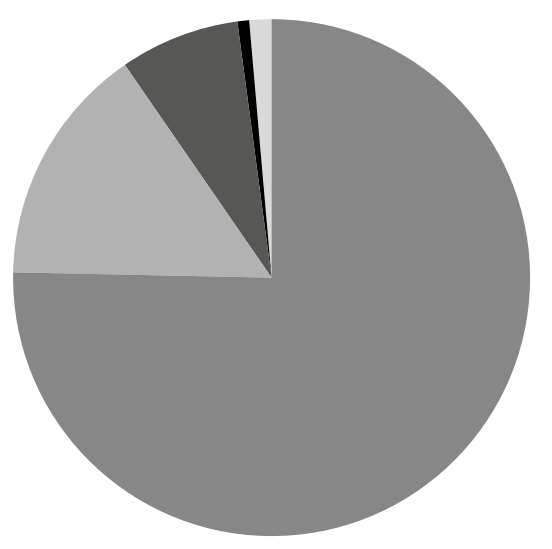

the state $€ 925 \mathrm{~m}$, (incl. holiday and stand-in scheme $€ 140 \mathrm{~m}$ and Support the Farmer Project $€ 2 \mathrm{~m}$ )

insurance premiums $€ 185 \mathrm{~m}$

other pension institutions $€ 92 \mathrm{~m}$

Social Insurance Institution of Finland (Kela) $€ 9 \mathrm{~m}$

investments $€ 17 \mathrm{~m}$

Source: Mela, Farmers' Social Insurance Institution of Finland, http://www.mela.fi, access 15.062020. 


\section{Types of benefits}

\section{Old age pension}

An old-age pension is the earnings-related pension a person has accrued during his/her working life. A person can retire on an old-age pension at the retirement age corresponding to his/her birth year. In other words, a person's year of birth affects when he/she can retire on an old-age pension.

Table 1. The retirement age increases gradually

\begin{tabular}{lll}
\hline Year of birth & $\begin{array}{l}\text { Retirement age/lowest age for } \\
\text { old-age pension }\end{array}$ & $\begin{array}{l}\text { Obligatory insurance ends/highest } \\
\text { age for old-age pension }\end{array}$ \\
\hline 1954 or earlier & 63 years & 68 years \\
\hline 1955 & 63 years and 3 months & 68 years \\
\hline 1956 & 63 years and 6 months & 68 years \\
\hline 1957 & 63 years and 9 months & 68 years \\
\hline 1958 & 64 years & 69 years \\
\hline$\ldots \ldots .$. & $\ldots \ldots . .$. & \\
\hline 1965 and later & $\begin{array}{l}\text { not yet decided }- \text { to be linked to } \\
\text { life expectancy }\end{array}$ \\
\hline
\end{tabular}

Source: Finnish Centre for Pensions ETK, http://etk.fi, access 15.062020.

\section{Flexible partial old-age pension}

A person can also retire on a partial old-age pension when he/she turns 61 . When a person retires on a partial old-age pension, he/she can draw $25 \%$ or $50 \%$ of the pension that he/she has accrued up to that time. Retiring early will permanently reduce his/her final old-age pension.

A person can work while receiving a partial old-age pension. There are no restrictions as to how much he/she can work or earn. Alternatively, a person can stop working altogether. 


\section{Disability pension}

A person may be granted a disability pension if his/her ability to work has been reduced for at least one year because of an illness, an injury or a handicap. For a disability lasting less than a year, a person may be granted a sickness allowance paid by the Finnish Social Insurance Institution.

The amount of the disability pension is calculated on the basis of the pension accrued before the incapacity for work begins. The amount of the disability pension may include the so-called future pension. Retirement for the coming period refers to the time between the onset of incapacity for work and the lowest retirement age. The pension for the coming period will be based on earnings for the five years preceding the onset of incapacity for work. The partial disability pension is half of the full disability pension.

A disability pension is granted if a persons' ability to work has been reduced by at least $60 \%$. Disability benefits can be granted as partial benefits if a person can cope with part-time work or lighter work tasks. A disability pension is granted to persons aged 60 and over on less stringent terms. If a person has reached the age of 60 , their ability to work is assessed in relation to his or her current job.

When a person reaches retirement age, his/her disability pension will be changed to an old-age pension.

If there is a chance that a person's ability to work might be restored, he/she will be granted a temporary cash rehabilitation benefit.

Table 2. Grade of work ability

\begin{tabular}{lll}
\hline Grade of work ability & $\begin{array}{l}\text { Pension granted until further } \\
\text { notice }\end{array}$ & $\begin{array}{l}\text { Pension granted for a temporary } \\
\text { period }\end{array}$ \\
\hline $\begin{array}{l}\text { Loss of work capacity } \\
\text { of at least } 60 \% \text { or more }\end{array}$ & Full disability pension & Cash rehabilitation benefit \\
\hline $\begin{array}{l}\text { Loss of work capacity } \\
\text { of } 40-59 \%\end{array}$ & Partial disability pension & Partial cash rehabilitation benefit \\
\hline
\end{tabular}

Source: Finnish Pension Alliance TELA, http://www.tela.fi, access 15.062020.

\section{Years-of-service pension after a long work history}

The years-of-service pension is intended for self-employed persons who have had a long and consuming working life, who have reached the age of 63 and whose ability to work has been permanently impaired. The years-of-service pension does 
not require such a large decrease in working capacity as a disability pension. The amount of the earnings-related pension is slightly lower than that of the disability pension.

The main criteria for the years-of-service pension:

- a person has worked in an occupation that requires great mental or physical effort for at least 38 years,

- his/her ability to work is reduced,

- he/she is still working or stopped working no earlier than one year earlier,

- he/she is 63 years of age or older,

- he/she has not yet reached his/her respective retirement age.

This type of pension is used very rarely.

\section{Survivors'pensions}

A survivor's pension may be paid to the spouse, children and, under certain conditions, common-law spouse of a policyholder whose death was caused by an occupational accident or disease.

A survivor's pension can be granted if a person's relationship to the deceased policyholder is one of the following:

- spouse,

- child under the age of 18 ,

- child under the age of 25 who is a full-time student,

- child under the age of 25 with a work disability.

The amount of the survivor's pension is calculated according to the annual calculated income of the deceased policyholder. The combined maximum amount of the survivor's pensions payable to the spouse and children is 70 percent of the annual earnings of the deceased policyholder.

The amount of the surviving spouse's pension may be at most half of the recipient's pension. The amount of a surviving child's pension depends on the number of surviving children who are beneficiaries. If there are several children, each child receives their own equal share of the child's pension.

\section{Accident and disease insurance}

MATA occupational accident and disease insurance is automatically valid for anyone covered by obligatory MYEL pension insurance. MATA personal accident insurance is available to anyone with MATA occupational accident and disease insurance. 
Occupational accident and disease insurance. Compensation for loss of earnings is a safeguard against incapacity for work caused by an accident or occupational disease. MATA occupational accident and disease insurance compensates expenses incurred as a result of an occupational accident or disease due to required treatment, medication and travel. The insurance also compensates the costs of physiotherapy, medical examinations and loss of income if there is good reason to believe that the injury or ailment is work-related.

Compensation for loss of earnings includes a daily allowance, an accident pension and a rehabilitation allowance.

A daily allowance may be paid if the insured's ability to work has deteriorated by at least 10 percent due to an accident or occupational disease. A daily allowance can also be paid as co-compensation if a person is not completely incapacitated. The reduction in working capacity is assessed on the basis of medical examinations.

The amount of a daily allowance is based on the calculated income at the time of the accident. If a person is completely incapacitated, the daily allowance is $1 / 360$ of his/her calculated income.

If incapacity continues beyond one year after the accident, the compensation for loss of earnings becomes an accident pension. The accident pension will continue as long as the incapacity persists.

The amount of the accident pension is determined on the basis of the annual calculated income. For persons aged under 65 , the full accident pension is 85 percent of the annual calculated income and for persons aged 65 or over -70 percent of the annual calculated income.

Loss of earnings during vocational rehabilitation is compensated by way of a rehabilitation allowance instead of a daily allowance or accident pension.

The amount of the rehabilitation allowance is equal to the amount of the daily allowance or accident pension.

Personal accident insurance. Alongside occupational MATA insurance, a person can have personal accident insurance for accidents that occur while performing household tasks, during leisure time or while travelling in Finland or abroad.

MATA personal accident insurance covers, for example, the cost of treatment, medicines and travel expenses. Treatment expenses are reimbursed without limit, and compensation is also paid for permanent disabilities. Compensation for loss of earnings includes a daily allowance and accident pension. Personal accident insurance does not provide sports or license insurance tailored for sports or licensed sports activities or travel insurance. When traveling abroad, a person should also have travel insurance, as personal accident insurance only covers the cost of treating injuries. 


\section{Farmers' holiday and stand-in scheme}

The farmers' holiday and stand-in scheme enable livestock farmers to call on help from farm relief workers to look after their animals while they take annual leave or, for example, sick leave. The annual leave entitlement for livestock farmers is 26 days per calendar year. The annual leave is free of charge. In addition, agricultural entrepreneurs can receive stand-in help and additional leave at a subsidised price due to illness, for example.

The farmers' holiday and stand-in scheme is intended to help livestock farmers cope at work by allowing them the opportunity to take a break from looking after their animals by themselves.

Livestock farmers can choose whether to use the stand-in services offered by the local administration or to arrange the stand-in help by themselves.

A farmer is eligible for holiday and stand-in services if he/she:

- works on a daily basis looking after farm animals,

- has obligatory MYEL insurance as an agricultural entrepreneur or a family member,

- conducts livestock production taxed in accordance with the Agricultural Income Tax Act,

- has at least 6 animal units,

- does not receive a blocking pension,

- works as a farmer on a full-time basis.

Farm relief workers are responsible for performing everyday livestock tasks. In other words, they perform all tasks that are essential for the well-being of farm animals.

Farm relief workers perform the tasks of the person who is on annual leave, receiving stand-in help or paying for subsidised stand-in help.

Stand-in services are organised by municipal authorities with which Mela has an agreement. These administrative regions, called local units, are responsible for making decisions related to the farmers' holiday and stand-in scheme.

Once a farmer has requested services from their local unit, the local unit will then make all the necessary arrangements. Generally, stand-in tasks are performed by farm relief workers who are employed by the municipal authorities. The farmer can also arrange the service him- or herself, in which case the local unit will pay compensation to the farmer.

In 2019, 15,000 farmers were entitled to annual leave, and the state reimbursed $€ 140$ million in costs for the farmers' holiday and stand-in scheme. 


\section{Mela sickness allowance}

The Mela sickness allowance is a benefit which is paid during the qualifying period for sickness allowance from the Finnish Social Insurance Institution. However, this allowance is not paid for the day of the initial doctor's visit or for the three following days. The Mela sickness allowance can be paid for up to six days. A sick leave certificate from a doctor is required.

The amount of the Mela sickness allowance is based on calculated income from the farm, and the daily allowance is $1 / 514$ of this income. In 2019 , nearly $€ 3$ million were paid in sickness allowances.

\section{Group life insurance}

After the death of an insured person, their widow(er) and children are entitled to a survivors' pension and compensation under group life insurance. Relatives are entitled to group life insurance compensation if the depositor has obligatory MYEL-insurance or the insurance expired no more than 3 years earlier.

The compensation is paid to the insured person's spouse, children under the age of 22 and, in certain circumstances, the unmarried partner of the insured person.

Group life insurance compensation is paid as a lump sum consisting of the widows' share, the children's share. The insurance amounts are confirmed by the Ministry of Social Affairs and Health.

In $2019, € 1$ million was paid out as group life insurance compensation in 65 cases.

\section{Occupational rehabilitation}

\section{Work pension rehabilitation}

Rehabilitation within the work-pension system means vocational rehabilitation arranged and paid for by pension companies, such as Mela. Its objective is to prevent disability and improve the opportunities for working when a person can no longer continue at his or her former job for health reasons. The intention is that a person can continue to work irrespective of an illness, injury or impairment. If a person is unable to continue his/her former work, occupational rehabilitation can help his/ her transfer to a new job or profession. The objective of vocational rehabilitation is that the total costs of rehabilitation remain below the corresponding pension expenditure. 
The main criterion for vocational rehabilitation is the threat of disability materialising within the next five years without rehabilitative action. Another important criterion is that this threat can be reduced by means of rehabilitation.

The right to vocational rehabilitation is conditioned upon the following preconditions being met:

- the applicant is professionally active,

- the applicant is unable to work or has a diagnosed medical condition that is likely to lead to a disability pension within the next few years,

- the threat of disability can be postponed or prevented by means of appropriate vocational rehabilitation,

- the applicant's earnings are at least $€ 36342.90$ (in 2020) during the five calendar years preceding the application,

- the applicant is currently employed or self-employed, or their termination of employment has happened recently,

- the applicant has not reached his/her old-age-retirement age,

- the applicant is not entitled to rehabilitation on the basis of accident insurance or motor liability insurance.

Work pension rehabilitation is provided annually in around 100 cases, and in approximately $80 \%$ of these, the customer is later employed.

\section{Occupational rehabilitation \\ in the event of an occupational accident or disease}

For occupational rehabilitation, Mela provides compensation for any essential procedures required to enable a person to continue his/her work, regardless of his/ her occupational injury or disease. If a person is unable to continue his/her former work, occupational rehabilitation can help his/her transfer to a new job or profession that will become his/her primary source of income.

Occupational rehabilitation is only available if it is required by an occupational accident or disease that is covered by MATA occupational accident and disease insurance. If work disability is not caused by an occupational accident or disease, a person may be eligible for work-pension rehabilitation.

The following support is included in occupational accident or disease rehabilitation:

- clarification of rehabilitation needs and options,

- job and education trial,

- job training for former job or a new job,

- applied education for a new job or profession,

- procurement of rehabilitation equipment for taking a new job, 
- financial assistance or an interest-free loan to support a new business or profession,

- financial assistance or an interest-free loan to procure a vehicle for travelling between home and a new workplace,

- reimbursement of costs of studies and study materials.

Accident and disease-related rehabilitation is provided annually in around 50100 cases, and in approximately $70-80 \%$ of these, the customer is later employed.

\section{Disability assessment}

When assessing reduced ability to work, both medical and socioeconomic factors such as education, work experience and age are also taken into consideration. The qualifying conditions for the disability pension are basically the same in all lines of business.

The assessment is based on the documentation a person includes with his/her disability pension application:

- medical statements issued by the attending medical doctor,

- a person's own description of his/her illness,

- his/her assessment of how he/she can cope at work.

If a person has turned 60 , his/her ability to work is assessed under more lenient conditions. The ability to work is assessed based on his/her last work task, the length of their working history and how he/she copes at work.

After receiving the application for a disability pension, including relevant medical documents, the degree of disability for work is assessed by an expert doctor employed by Mela. The decision on disability for work is made on the basis of an opinion issued by the expert doctor.

For accident insurance applications, the procedure is very similar. For such applications, the causal link of the accident is also assessed.

\section{Prevention}

\section{Occupational well-being activities}

Mela's occupational well-being activities aim to enhance the occupational safety and well-being of our customers by providing services that support occupational well-being. 
Today farmers are living under increasing mental pressure: low profitability, major investments, an ever-increasing workload, problems within the family and many other reasons are causing serious threats to farmers' mental well-being. In the worst case scenario, these reasons can lead to farmer's permanent disability and jeopardise the future of farming. "Early Intervention" and "Taking Care of Farmers" are schemes which promote farmers' ability to continue working.

Getting help starts with contacting the project worker, who'll help figure out the overall situation and listen to a farmer. Together they look for ways to help the farmer cope with, among other things, difficult family situations, the challenges of entrepreneurship on a farm and financial problems.

A farmer can also apply for a purchase service commitment worth $€ 500$. Purchase service commitments are granted to support farmers' mental health (e.g. therapy and work guidance), and other expert assistance is also available in support of this. The farmer in question must use the benefit himself/herself, it cannot be transferred, for example, to the spouse.

\section{Occupational health services}

The purpose of occupational health care is to prevent work-related illnesses and accidents. A farmer can choose to arrange preventive occupational health care coverage for him- or herself. He/she can arrange to get it from a municipal health centre, a private medical clinic or a self-employed health care professional.

Mela promotes the development of farmers' occupational health care in many ways, including through the use of these services.

\section{Occupational safety work}

Mela also promotes the occupational safety work of farmers at a general level by funding research activities and providing information related to occupational safety.

\section{Mela's organisation}

MELA is an employment pension company established by virtue of law, which is exceptional in the Finnish decentralised employment pension insurance system. Due to this special status and the significant share of state funding, government ministries have an important role in MELA's administration: the Ministry of Social 
Affairs and Health, the Ministry of Agriculture and the Ministry of Finance are represented on the board of Mela.

Mela's highest decision-making power is exercised by a delegation of 15 members. The chair of the delegation is appointed by the Central Union of Agricultural and Forestry Producers (MTK). Ten of the members of the delegation are appointed by Mela's insured organisations to control its financial interests. In addition, the delegation includes members from the Ministry of Agriculture and Forestry, the Ministry of Social Affairs and Health, and the Ministry of Finance.

Mela's Board of Directors has 9 members. The Chair represents the Central Union of Agricultural and Forestry Producers (MTK). Mela's delegation elects four Mela insurance customer representatives to the Board of Directors. In addition, the Board of Directors includes members from the Ministry of Agriculture and Forestry, the Ministry of Social Affairs and Health, and the Ministry of Finance

Mela has 200 employees, 160 of whom work at the head office in Espoo. Local agents (35) provide face-to-face service at the provincial level. The organisation chart of Mela is as follows:

\section{Figure 1. Mela's organisation}

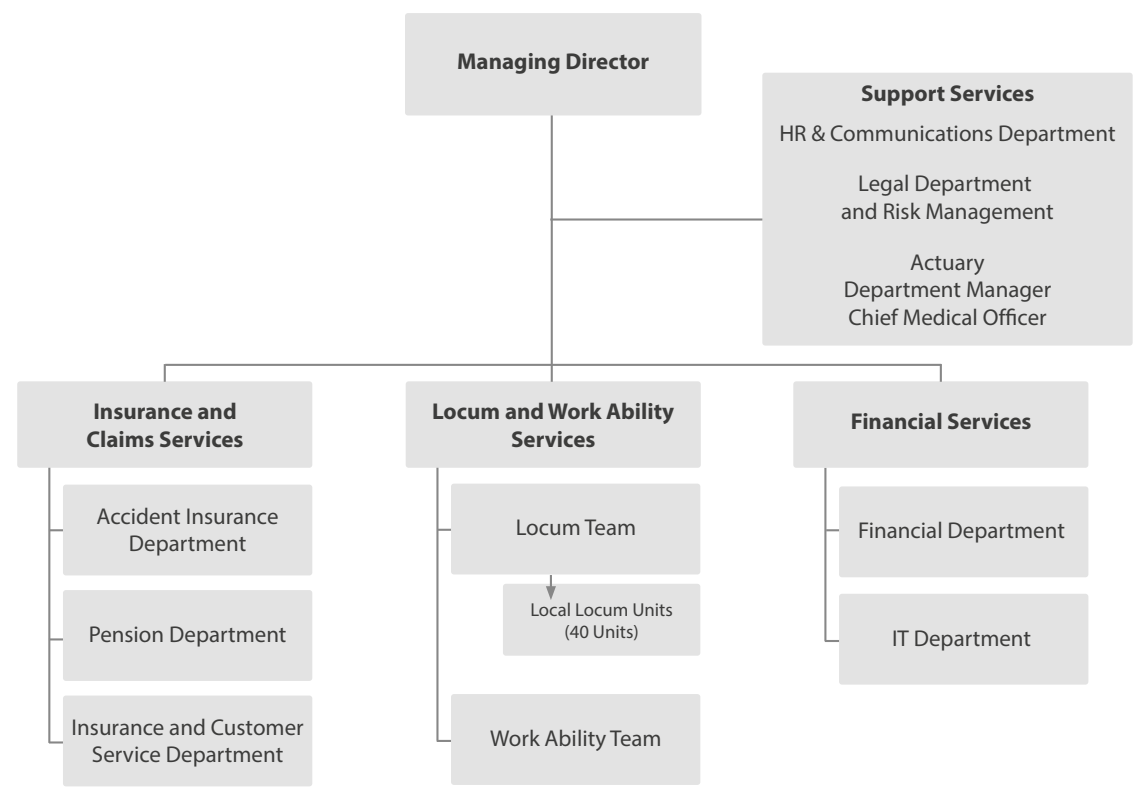




\section{International cooperation}

Mela is an active member of ENASP and the ISSA Agriculture Section.

\section{Summary}

Mela offers its customers comprehensive cover and ensures their well-being in all life situations. Mela's primary task is to implement the earnings-related pension scheme for farmers and other insured persons. Insured persons of working age are also automatically covered by a sickness allowance and occupational accident insurance. Personal accident insurance can be added to occupational accident insurance.

Those who have lost their working capacity can retire on a disability pension. Rehabilitation is used to improve the opportunities of farmers and grant recipients to continue in their current job or acquire training for a new occupation. As they approach retirement age, insured persons can receive a part-time pension. It is possible to retire on an old-age pension at the age of 63-68 years. After the death of an insured person, their widow(er) and children are entitled to a survivor's pension and compensation from group life insurance.

Use of farmer's holiday substitutes contributes to the well-being of livestock farmers. Mela is responsible for the implementation of farmer's holiday and standin services. In practice, locum services are handled by local units. The occupational health services support entrepreneurs and help farmers in maintaining their health and working capacity. Mela also provides information and guidance in relation to occupational safety issues. 


\section{Bibliography}

ETK, Finnish Centre for Pensions, http://etk.fi, access 15.06.2020.

Kela, Social Insurance Institution of Finland, http://www.kela.fi, access 15.06.2020.

Mela, Farmers' Social Insurance Institution of Finland, http://www.mela.fi, access 15.062020.

TELA, Finnish Pension Alliance, http://www.tela.fi, access 15.06.2020.

This article is licensed under a Creative Commons Attribution 4.0 International license (CC BY 4.0) 